\title{
The Current Status of the Tiger Beetle Species of the Coastal Habitats of Sri Lanka
}

\author{
C. D. Dangalle ${ }^{1}$ \\ ${ }^{1}$ Department of Zoology, University of Colombo, Colombo 03
}

Date Received: 19-04-2013 Date Accepted: 12-09-2013

\begin{abstract}
The species of tiger beetles inhabiting coastal habitats of Sri Lanka have not been studied for nearly three decades. We report the tiger beetle species currently occupying the coastal habitats of the island, their distribution, microhabitats and habitat preferences. Species and distributions reported nearly three decades from similar previous studies are also recorded. Southern, North-Western and Western coastal belts $(n=22)$ of Sri Lanka were investigated for the presence of tiger beetles. Three species, Hypaetha biramosa, Lophyra (Lophyra) catena, Myriochila (Monelica) fastidiosa, were recorded from eleven locations. M. (Monelica) fastidiosa was reported for the first time, in a single location of the Southern coastal belt. Habitat parameters of the locations and the length of the body and mandible between H. biramosa and L. (Lophyra) catena, were statistically compared to determine specific habitat preferences of the two species. Analysis of Variance using Minitab 16.0 revealed that $H$. biramosa occupy habitats with high solar radiation $\left(438-1023 \mathrm{w} / \mathrm{m}^{2}\right)$ and soil salinity (0.0-0.1ppt) while L. (Lophyra) catena occupy habitats with low solar radiation (132-402) and non-saline soils $(0.0 \mathrm{ppt})$. Similar length of mandibles of these two species indicated that habitat selection of the species was not based on prey utilization, but may depend on the intensity of solar radiation and the level of soil salinity of the locations.
\end{abstract}

Keywords: tiger beetles, coastal habitats, distribution, habitat preferences, Sri Lanka

\section{Introduction}

Tiger beetles (Coleoptera, Cicindelidae) are a group of predatory insects that are distributed throughout the world (Pearson, 1988). About twenty-seven hundred (2,700) species have been described so far in almost every part of the terrestrial world except Antarctica, Tasmania and smaller oceanic islands and atolls (Pearson, 2011). They occur in a wide variety of habitats which differ greatly in physical structure, soil characteristics and plant composition, but share the presence of bare patches of open ground (Knisley, 2011). Each species rarely occurs in more than one or a very few habitat types and habitat associations tend to be highly specific (Morgan et al., 2000; Rafi et al., 2010). One of the most common habitat types of tiger beetles are coastal areas with ocean beaches, sand dunes, sand bars, salt flats, estuaries, rocky shores, tidal flats with reeds and lagoons (Wiesner, 1975; Satoh et al., 2003; Knisley and Fenster, 2005; Knisley, 2011). Many species inhabit these environments and larvae and adults of tiger beetles typically occur in the same microhabitat (Knisley, 2011). However, in recent years population declines have been noted in many species due to the spatial and temporal changes in coastal areas caused by flooding, erosion of the coast, deposition of sediments by water and wind, and anthropogenic activities (Mawdsley, 2009; Mouna et al., 2011). Populations of North American tiger beetle species, Cicindela dorsalis dorsalis and Cicindela puritana have declined due to trampling of larval burrows by foot and vehicles (Mawdsley, 2009). Ohlone tiger beetle (Cicindela ohlone) that occurs in coastal terrace grassland has experienced loss of several populations due to

* Correspondence: cddangalle@gmail.com

Tel: +9477345563

ISSN 2235-9370 Print / ISSN 2235-9362 Online @2013 University of Sri Jayewardenepura 
encroachment of invasive grasses and herbaceous vegetation (Knisley, 2011). Cicindela hirticollis of North America has declined because of human construction and habitat alteration of the shoreline and increased beach usage and other human disturbances along the coast (Knisley and Fenster, 2005). However, while much is known about the coastal habitats, habitat threats and ecology of North American and European tiger beetles, very little has been published on species of other countries. Information about the locations, habitats and habitat preferences play an important role in the development of conservation strategies for these insects.

Seven species of tiger beetles have been recorded from the coastal areas of Sri Lanka (Weisner, 1975; Naviaux, 1984; Acciavatti and Pearson, 1989) (Table 1 and Figure 1). Hypaetha biramosa is confined to the sandy ocean beaches and calm bays of the island while the other species can be found in coastal habitats and other inland localities away from the coast. Callytron limosa, Hypaetha quadrilineata, Myriochila (Monelica) distinguenda, Cylindera (Eugrapha) singalensis, Lophyra (Lophyra) cancellata have been recorded along major rivers, brackish mud puddles and inland lakes, whereas Lophyra (Lophyra) catena occupies upland areas of open grassland, old fields, dirt roads and margins of rivers (Acciavatti and Pearson, 1989). None of these species are endemic. They occur in countries of the Indian subcontinent in India, Pakistan, Burma, Bangladesh, Nepal and in South-east Asia, Thailand, China and Malaysia (Acciavatti and Pearson, 1989). As indicated in Table 1 these species have not been reported since 1984. Therefore, current distributions, habitat and their characteristics remain uncertain.

Table 1: Tiger beetle species recorded from coastal locations of Sri Lanka

\begin{tabular}{|c|c|c|}
\hline Species & Microhabitat & $\begin{array}{l}\text { Location (Recorded year and reference } \\
\text { given within brackets) }\end{array}$ \\
\hline Callytron limosa & Along the coast. & $\begin{array}{l}\text { Chilaw (1979) \{Acciavatti and Pearson, } \\
1989\}\end{array}$ \\
\hline Hypaetha biramosa & $\begin{array}{l}\text { Intertidal zone and undisturbed } \\
\text { outer sandy ocean beaches. On the } \\
\text { sea shore not more than } 200 \text { yards } \\
\text { from the edge of the sea. Sea border } \\
\text { on clean, level sandy banks. Prefers } \\
\text { calm bays. }\end{array}$ & $\begin{array}{l}\text { Mannar (1981), Pesalai (1981), } \\
\text { Trincomalee (1972) \{Acciavatti and } \\
\text { Pearson, 1989\} } \\
\text { Galle (1970), Hikkaduwa (1970), } \\
\text { Hendala (1979), Kalutara (1979), } \\
\text { Nilaveli (1981), Kalkudah (1981), } \\
\text { Pottuvil (1983) } \\
\text { \{Naviaux, 1984\} }\end{array}$ \\
\hline Hypaetha quadrilineata & Sandy areas along coastal beaches. & Colombo $\{$ Horn, 1904$\}$ \\
\hline $\begin{array}{l}\text { Myriochila (Monelica) } \\
\text { distinguenda }\end{array}$ & $\begin{array}{l}\text { Brackish mud puddles near the } \\
\text { ocean. }\end{array}$ & $\begin{array}{l}\text { Puttalam (1981), Padaviya (1970), } \\
\text { Kilinochchi (1970), Mannar (1976) } \\
\text { \{Acciavatti and Pearson, 1989\} }\end{array}$ \\
\hline $\begin{array}{l}\text { Cylindera (Eugrapha) } \\
\text { singalensis }\end{array}$ & $\begin{array}{l}\text { Flat, muddy open places near the } \\
\text { sea. }\end{array}$ & $\begin{array}{l}\text { Hambantota (1921) \{ Acciavatti and } \\
\text { Pearson, 1989\} }\end{array}$ \\
\hline $\begin{array}{l}\text { Lophyra (Lophyra) } \\
\text { cancellata }\end{array}$ & Dry, warm ground close to the sea. & $\begin{array}{l}\text { Colombo (1970), Galle (1970), } \\
\text { Hikkaduwa (1970) \{Weisner, 1975\} }\end{array}$ \\
\hline $\begin{array}{l}\text { Lophyra (Lophyra) } \\
\text { catena }\end{array}$ & Lagoons by the ocean. & $\begin{array}{l}\text { Hendala (1979), Bentota (1979), } \\
\text { Puttalam (1981) \{ Naviaux, 1984\} } \\
\text { Aluthgama (1984) \{Acciavatti and } \\
\text { Pearson, 1989\} }\end{array}$ \\
\hline
\end{tabular}




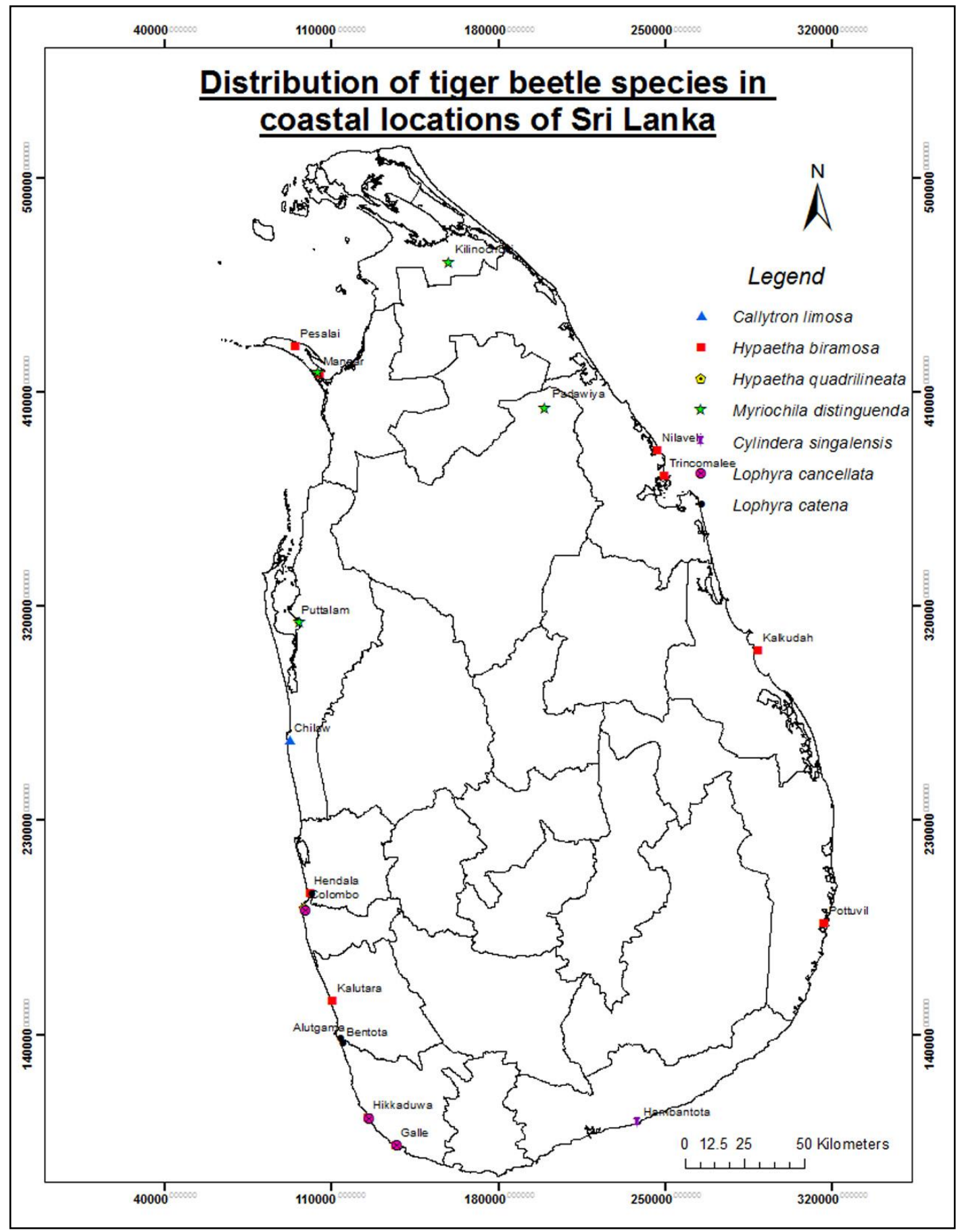

Figure 1: Distribution of tiger beetle species in coastal locations of Sri Lanka

The coastal ecosystems of Sri Lanka provide the basis for the marine fisheries industry and coastal tourism, while serve as a host of other economic and social benefits (IUCN 2002). These activities, most notably ill-designed coastal structures, construction of hotels and other buildings too near the shoreline, sand and coral mining, removal of coastal vegetation and reef breaking have contributed to coastal erosion and have resulted in the degradation and loss of coastal land (Lowry and Wickremeratne, 1988). Further, in December 2004, the Sri Lankan coastline was devastated by the Indian Ocean Tsunami and the entire coastline with the exception of parts of the North-Western coastline was severely affected. Coastal tiger beetles are known to be very sensitive to disturbances on the coastline and they are known to experience population bottlenecks caused by natural disasters such as storms or tsunami (Satoh et al., 2004; Mawdsley, 
2009). Therefore, it is imperative that the species inhabiting the coastal areas of Sri Lanka be recorded and investigated. The present study intends to record the tiger beetle species of coastal habitats of Sri Lanka, investigate the current locations and distribution of tiger beetle species of Sri Lanka, study the microhabitats and habitat segregation of species and record habitat preferences of each species. The study will provide information for assessing the conservation status of coastal tiger beetles of Sri Lanka and for providing habitat management strategies for the group.

\section{Methodology}

\subsection{Study Area}

Twenty-two (22) coastal locations of Sri Lanka were surveyed for the occurrence of tiger beetles from May 2003 to March 2008. The locations were situated in the North-Western, Western and Southern provinces of Sri Lanka in the districts of Puttalam, Gampaha, Colombo, Kalutara, Galle, Matara and Hambantota (Table 2 and Figure 2). Sandy beaches, areas with vegetation, paths and trails, rocks, salt flats, sand bars and sand dunes were searched for tiger beetles between 09.00-17.00 h.

\subsection{Collection and identification of tiger beetle species}

Tiger beetles were collected using a standard insect net and preserved in $70 \%$ alcohol. Permission to make collections of tiger beetles was obtained through a permit issued by the Department of Wildlife Conservation, Ministry of Environment and Natural Resources of Sri Lanka.

Taxonomic keys of the Cicindela of the Indian Subcontinent by Acciavatti and Pearson (1989), descriptions of Horn (1904) and Fowler (1912) were used to identify the species and confirmation of identification was done through comparisons with type specimens available at the National Museum of Colombo and Natural History Museum, London. Taxonomic names of species with the present nomenclatural changes are based on Weisner, 1992.

\subsection{Measurement of body length and mandible length}

Body length and mandible length were estimated for thirty-three tiger beetles. The thirty-three specimens consisted of fifteen specimens of Hypaetha biramosa, fifteen specimens of Lophyra (Lophyra) catena and three specimens of Myriochila (Monelica) fastidiosa (Table 3).

Body length was estimated by measuring the distance from the frons of the head to the elytral apex when the head was in the normal feeding position. Caudal spines on the elytral apex were disregarded. Based on the references of Acciavatti and Pearson (1989), McCairns et al. (1997) and Zerm and Adis (2001), body length of beetles was categorized as follows.

Less than $8 \mathrm{~mm}$ - Very small

8 to $10 \mathrm{~mm}$ - Small

10 to $15 \mathrm{~mm}$ - Medium

15 to $20 \mathrm{~mm}$ - Large

More than $20 \mathrm{~mm}$ - Very large

Mandible length was estimated by measuring the distance from the articulation point to the tip of the left mandible. Based on Pearson and Juliano (1993) and Satoh and Hori (2004) mandibles of beetles were categorized according to the following size groups.

$$
\begin{aligned}
& <2 \mathrm{~mm}-\text { Small } \\
& 2 \text { to } 3 \mathrm{~mm}-\text { Medium } \\
& >3 \mathrm{~mm}-\text { Large }
\end{aligned}
$$


Measurements of both body length and mandible length were taken using a dissecting microscope (Nikon Corporation SE, Japan) with an eyepiece graticule (Nikon, Tokyo, Japan) that was calibrated by an objective micrometer (Olympus, Japan).

Body length and mandible length of H. biramosa and L. (Lophyra) catena were compared using OneWay Analysis of Variance (Minitab 16.0) and the $\mathrm{P}$ statistic at 95\% significance was calculated. Morphological parameters of M. (Monelica) fastidiosa were not subjected to statistical analysis as only three specimens were found from a single location, a number too low for statistical comparison. Boxplots were created for the morphological measurements that were significant between H. biramosa and L. (Lophyra) catena using Boxplot option in Graphs (Minitab 16.0).

Table 2: Coastal locations of Sri Lanka investigated for tiger beetles

\begin{tabular}{|c|c|}
\hline Location & Date of Investigation \\
\hline Puttalam Lagoon, Puttalam district, North-Western province & June 2004 \\
\hline Mundel Lake, Puttalam district, North-Western province & June 2004 \\
\hline Chilaw coast, Puttalam district, North-Western province & June 2004 \\
\hline Marawila coast, Puttalam district, North-Western province & June 2004 \\
\hline Poruthota coast, Gampaha district, Western province & June 2004 \\
\hline Mount Lavinia beach, Colombo district, Western province & October 2004, March 2008 \\
\hline Thalpitiya coast, Kalutara district, Western province & June 2004 \\
\hline Katukurunda coast, Kalutara district, Western province & June 2004, July 2006 \\
\hline Maggona coast, Kalutara district, Western province & June 2005 \\
\hline Aluthgama coast, Kalutara district, Western province & June 2004, July 2006 \\
\hline Bentota beach, Galle district, Southern province & March 2008 \\
\hline Induruwa coast, Galle district, Southern province & June 2005 \\
\hline Kosgoda beach, Galle district, Southern province & May 2003, November 2005 \\
\hline Galle Harbor, Galle district, Southern province & March 2005 \\
\hline Kathaluwa coast, Galle district, Southern province & March 2005 \\
\hline Morampitigoda coast, Galle district, Southern province & March 2005 \\
\hline Habaraduwa beach, Galle district, Southern province & May 2003, August 2007 \\
\hline Matara beach, Matara district, Southern province & May 2003, August 2007 \\
\hline Hambantota salt flats, Hambantota district, Southern province & November 2004 \\
\hline Hambantota beach, Hambantota district, Southern province & November 2004 \\
\hline Kirinda, Hambantota district, Southern province & November 2005 \\
\hline Yala Salterns, Hambantota district, Southern province & November 2005 \\
\hline
\end{tabular}




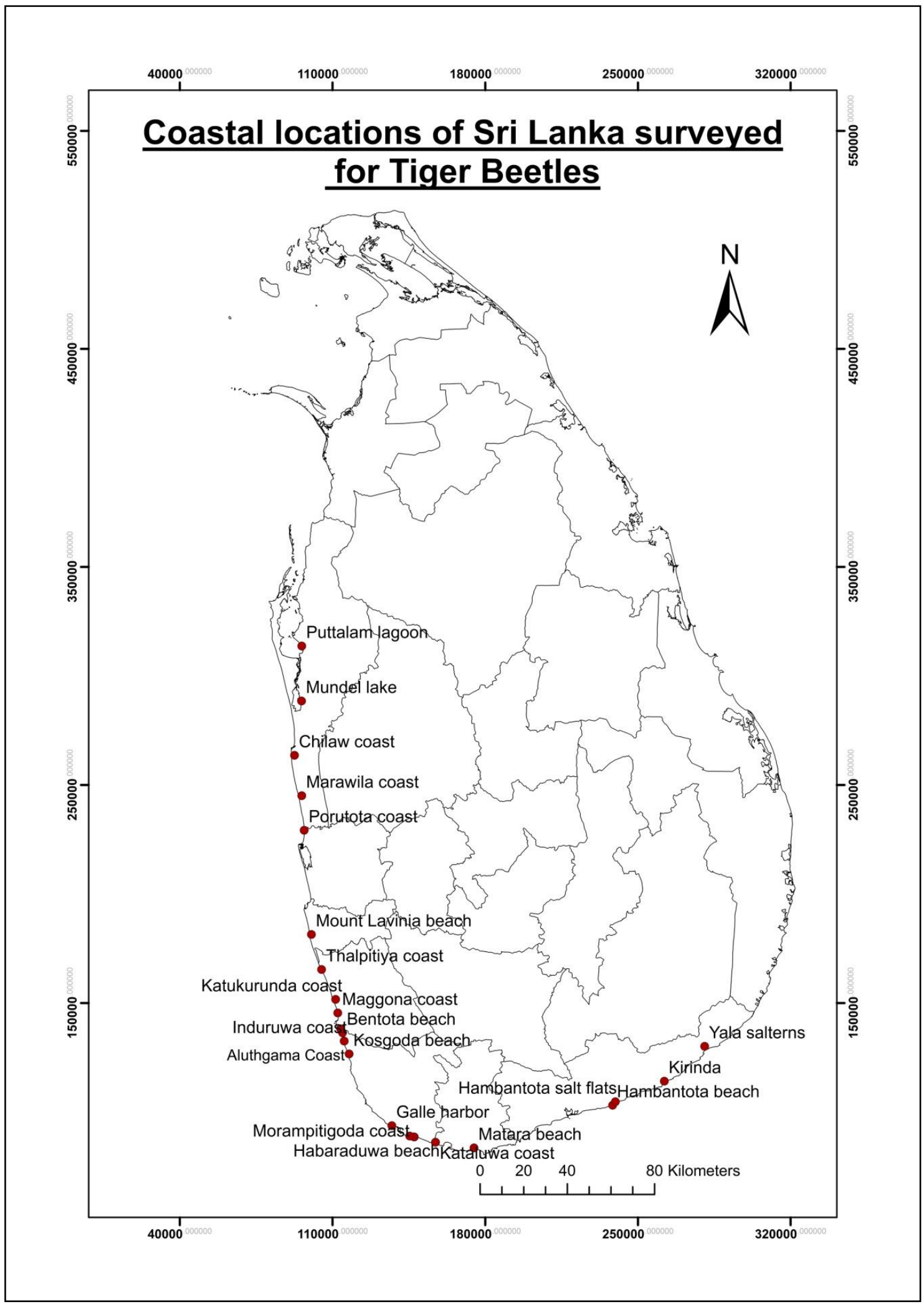

Figure 2: The coastal locations of Sri Lanka investigated for the presence of tiger beetles

\subsection{Measurement of habitat parameters}

Spatial coordinates and elevation was recorded using a marine/outdoor geographical positioning system device (GPS 315, Magellan Systems Corp., Taiwan). Air temperature, solar radiation, relative 
humidity and wind speed was measured using a portable integrated weather station (Health EnviroMonitor, Davis Instrument Corp., USA). A soil sample of the habitat was used to determine the soil temperature (using Insert soil thermometer SG 680-10), soil moisture (determined by selecting five random spots of a locality and collecting samples to a depth of $10 \mathrm{~cm}$ and estimating the difference in weight before and after oven drying to $107-120^{\circ} \mathrm{C}$ in the laboratory), soil $\mathrm{pH}$ (using portable soil $\mathrm{pH}$ meter Westminister No.259) and soil salinity (using a YSI model 30 hand-held salinity meter). Vegetation type and distribution was also noted.

Habitat parameters of the locations of H. biramosa and L. (Lophyra) catena were compared using One-Way Analysis of Variance (Minitab 16.0) and Tukey's Multiple Comparison method. Habitat parameters of M. (Monelica) fastidiosa were not subjected to statistical analysis as the species was found only in one location. Boxplots were created for the habitat parameters that were significant between $H$. biramosa and L. (Lophyra) catena using Boxplot option in Graphs (Minitab 16.0). Further, habitat parameters of the locations of tiger beetles were compared with the locations in which tiger beetles were not recorded using the same statistical procedure.

\section{Results}

\subsection{Locations of tiger beetle species}

Tiger beetles were encountered in eleven (11) coastal locations of Sri Lanka in the districts of Puttalam, Kalutara, Galle, Matara and Hambantota (Table 4). Species recorded before the 2004 tsunami were encountered in the same locations after the tsunami (Table 2). Three tiger beetle species, Hypaetha biramosa Fabricius 1781, Lophyra (Lophyra) catena Fabricius 1775, Myriochila (Monelica) fastidiosa Dejean 1825, were found in these locations between 09.30-16.30 h (Table 4 and Figure 3). H. biramosa was found on the sandy beach near the swash where there was no vegetation, while L. (Lophyra) catena occupied areas with vegetation about $25 \mathrm{~m}$ inland from the beach. Both species were found together at Bentota beach in which $H$. biramosa occupied the shore near the water edge, while L. (Lophyra) catena occupied the more inland area away from the shore. M. (Monelica) fastidiosa occurred in only one location, near the water edge of a salt flat (Table 4).

Table 4: Coastal locations of tiger beetle species recorded in the study

\begin{tabular}{|c|c|c|c|}
\hline Location & $\begin{array}{l}\text { Coordinates and } \\
\text { Elevation }\end{array}$ & Species & Microhabitat \\
\hline $\begin{array}{l}\text { Chilaw coast, Puttalam district, } \\
\text { North-Western province }\end{array}$ & $\begin{array}{l}7^{\circ} 34^{`} 79 \mathrm{~N} \\
79^{\circ} 47^{`} 27 \mathrm{E} \\
0.00 \mathrm{~m}\end{array}$ & $\begin{array}{l}\text { Lophyra (Lophyra) } \\
\text { catena }\end{array}$ & Sand dunes \\
\hline $\begin{array}{l}\text { Katukurunda coast, Kalutara } \\
\text { district, Western province }\end{array}$ & $\begin{array}{l}6^{\circ} 33^{`} 28 \mathrm{~N} \\
79^{\circ} 57^{`} 92 \mathrm{E} \\
9.75 \mathrm{~m}\end{array}$ & $\begin{array}{l}\text { Lophyra (Lophyra) } \\
\text { catena }\end{array}$ & $\begin{array}{l}\text { Amongst } \\
\text { vegetation away } \\
\text { from the beach }\end{array}$ \\
\hline $\begin{array}{l}\text { Bentota beach, Galle district, } \\
\text { Southern province }\end{array}$ & $\begin{array}{l}6^{\circ} 23^{\circ} 99 \mathrm{~N} \\
80^{\circ} 00^{`} 26 \mathrm{E} \\
0.00-9.50 \mathrm{~m}\end{array}$ & $\begin{array}{l}\text { Hypaetha biramosa } \\
\text { Lophyra (Lophyra) } \\
\text { catena }\end{array}$ & $\begin{array}{l}\text { Sandy beach } \\
\text { Amongst } \\
\text { vegetation away } \\
\text { from the beach }\end{array}$ \\
\hline $\begin{array}{l}\text { Induruwa coast, Galle district, } \\
\text { Southern province }\end{array}$ & $\begin{array}{l}6^{\circ} 22^{\prime} 05 \mathrm{~N} \\
80^{\circ} 00^{\prime} 68 \mathrm{E} \\
8.00 \mathrm{~m}\end{array}$ & Hypaetha biramosa & Wet sandy beach \\
\hline $\begin{array}{l}\text { Kosgoda beach, Galle district, } \\
\text { Southern province }\end{array}$ & $\begin{array}{l}6^{\circ} 21^{`} 24 \mathrm{~N} \\
80^{\circ} 00^{`} 59 \mathrm{E} \\
1.40 \mathrm{~m}\end{array}$ & Hypaetha biramosa & Wet sandy beach \\
\hline
\end{tabular}




\begin{tabular}{|c|c|c|c|}
\hline Location & $\begin{array}{l}\text { Coordinates and } \\
\text { Elevation }\end{array}$ & Species & Microhabitat \\
\hline $\begin{array}{l}\text { Aluthgama coast, Kalutara district, } \\
\text { Western province }\end{array}$ & $\begin{array}{l}6^{\circ} 23^{`} 58 \mathrm{~N} \\
80^{\circ} 00^{`} 33 \mathrm{E} \\
9.14 \mathrm{~m}\end{array}$ & $\begin{array}{l}\text { Lophyra (Lophyra) } \\
\text { catena }\end{array}$ & $\begin{array}{l}\text { Footpath } \\
\text { amongst } \\
\text { vegetation away } \\
\text { from the beach }\end{array}$ \\
\hline $\begin{array}{l}\text { Morampitigoda coast, Galle } \\
\text { district, Southern province }\end{array}$ & $\begin{array}{l}6^{\circ} 02 ` 33 \mathrm{~N} \\
80^{\circ} 01^{`} 41 \mathrm{E} \\
0.00 \mathrm{~m}\end{array}$ & Hypaetha biramosa & Wet sandy beach \\
\hline $\begin{array}{l}\text { Habaraduwa beach, Galle district, } \\
\text { Southern province }\end{array}$ & $\begin{array}{l}6^{\circ} 02 ` 11 \mathrm{~N} \\
80^{\circ} 11^{`} 45 \mathrm{E} \\
0.00 \mathrm{~m}\end{array}$ & Hypaetha biramosa & Sandy beach \\
\hline $\begin{array}{l}\text { Matara beach, Matara district, } \\
\text { Southern province }\end{array}$ & $\begin{array}{l}6^{\circ} 03^{`} 11 \mathrm{~N} \\
80^{\circ} 12^{`} 26 \mathrm{E} \\
0.09 \mathrm{~m}\end{array}$ & Hypaetha biramosa & Sandy beach \\
\hline $\begin{array}{l}\text { Hambantota salt flats, Hambantota } \\
\text { district, Southern province }\end{array}$ & $\begin{array}{l}6^{\circ} 07^{\circ} 00 \mathrm{~N} \\
81^{\circ} 03^{`} 00 \mathrm{E} \\
1.00 \mathrm{~m}\end{array}$ & $\begin{array}{l}\text { Myriochila } \\
\text { (Monelica) fastidiosa }\end{array}$ & Near water edge \\
\hline $\begin{array}{l}\text { Kirinda, Hambantota district, } \\
\text { Southern province }\end{array}$ & $\begin{array}{l}6^{\circ} 13^{`} 78 \mathrm{~N} \\
81^{\circ} 19^{`} 11 \mathrm{E} \\
3.02 \mathrm{~m}\end{array}$ & $\begin{array}{l}\text { Lophyra (Lophyra) } \\
\text { catena }\end{array}$ & $\begin{array}{l}\text { Foot path } \\
\text { amongst } \\
\text { vegetation }\end{array}$ \\
\hline
\end{tabular}

\subsection{Body length and mandible length}

All three species of coastal tiger beetles were medium sized with body lengths ranging from 10.38-13.63 $\mathrm{mm}$ and mandible lengths ranging from 1.50-2.58 $\mathrm{mm}$ (Table 3). The body lengths of H.biramosa and L.(Lophyra) catena were significantly different $(\mathrm{F}=8.4, \mathrm{P}=0.007)$, L. (Lophyra) catena being slightly smaller than $H$. biramosa (Table 3 and Figure 4). The mandible lengths of the two species did not differ significantly.

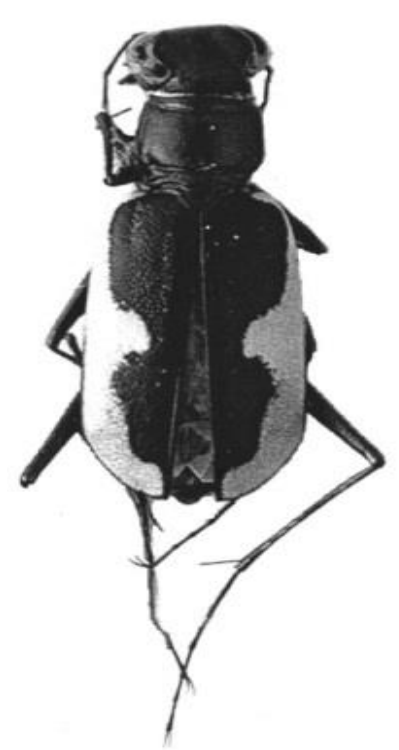

Hypaetha biramosa

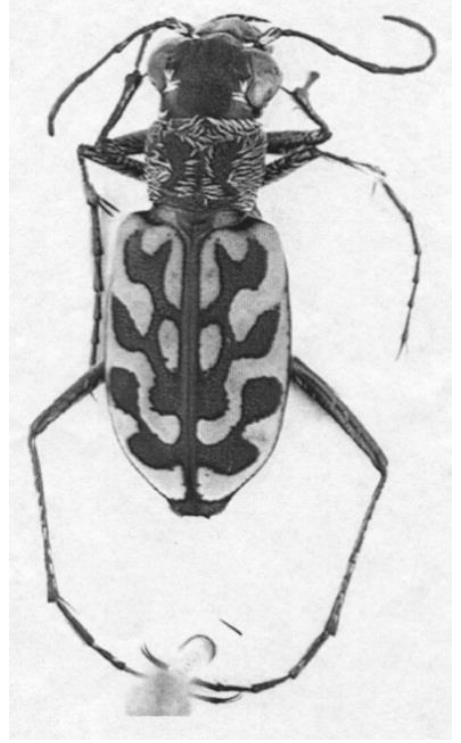

Lophyra (Lophyra) catena

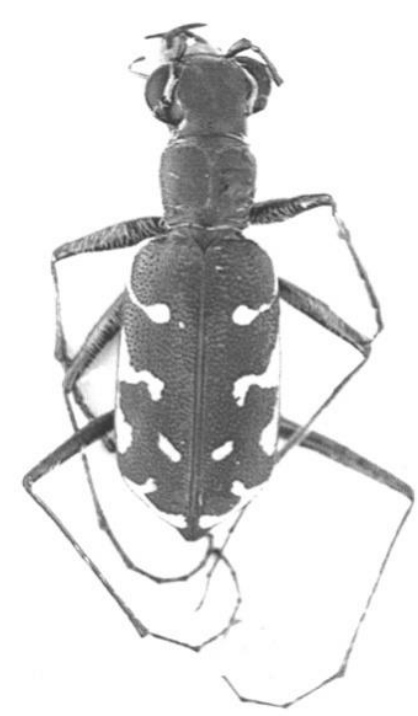

Myriochila (Monelica) fastidiosa

Figure 3: The coastal tiger beetle species of Sri Lanka 
Table 3: Mean body length and mandible length of coastal tiger beetle species \pm standard error and range in parentheses

\begin{tabular}{lccc}
\hline Species & $\begin{array}{c}\text { Number of } \\
\text { specimens }\end{array}$ & $\begin{array}{c}\text { Average body length } \\
(\mathrm{mm})\end{array}$ & $\begin{array}{c}\text { Average mandible } \\
\text { length }(\mathrm{mm})\end{array}$ \\
\hline $\begin{array}{l}\text { Hypaetha biramosa } \\
\text { Lophyra (Lophyra) }\end{array}$ & 15 & $12.10 \pm 0.24^{*}$ & $1.69 \pm 0.19$ \\
catena & 15 & $(10.50-13.63)$ & $(1.50-2.08)$ \\
$\begin{array}{l}\text { Myriochila } \\
\text { (Monelica) fastidiosa }\end{array}$ & 03 & $\left(11.27 \pm 0.16^{*}\right.$ & $2.42 \pm 0.05$ \\
& & $11.21 \pm 0.65$ & $(2.23-2.58)$ \\
& & $(10.38-12.50)$ & $2.24 \pm 0.13$ \\
\end{tabular}

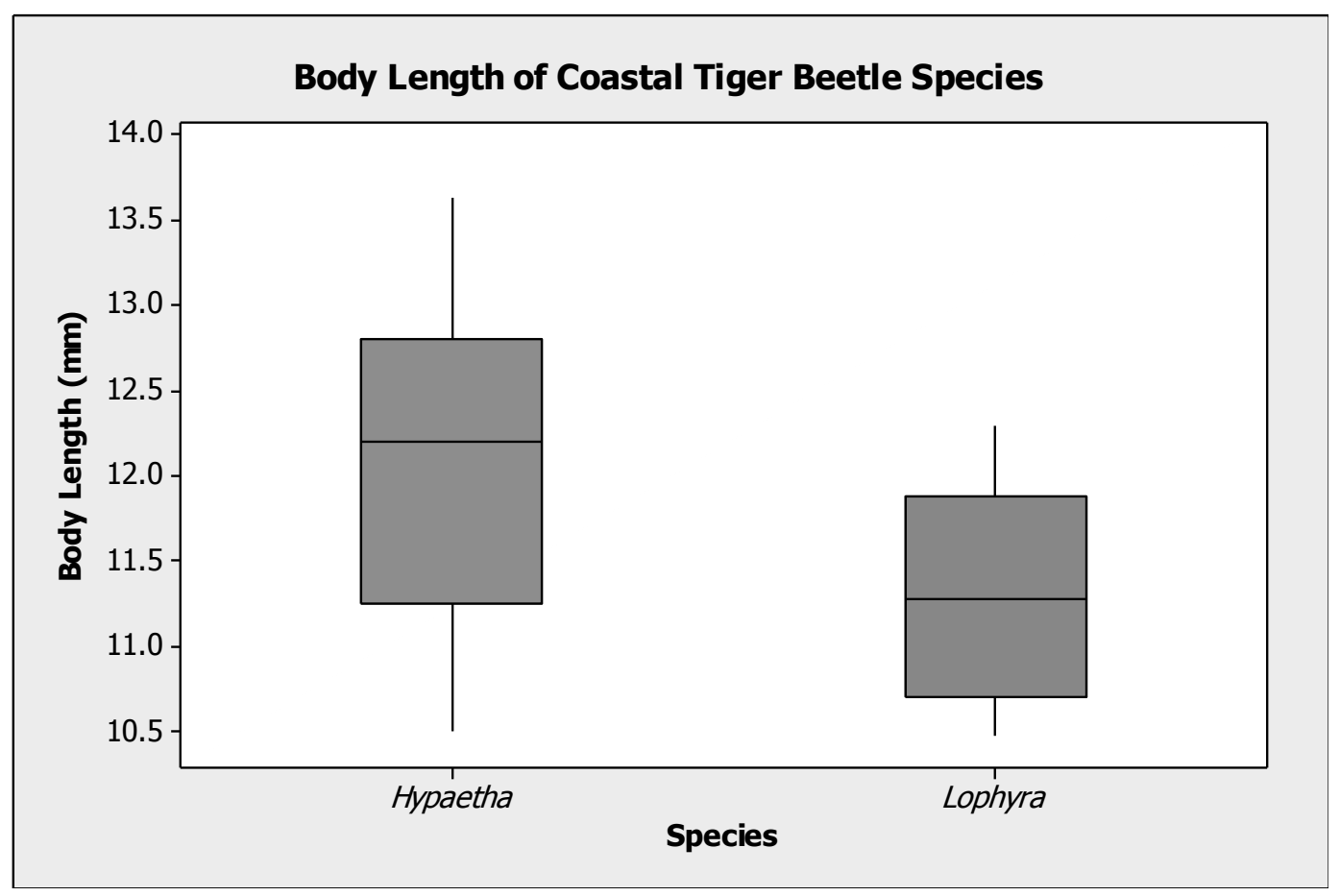

Figure 4: Body length variation of Hypaetha biramosa and Lophyra (Lophyra) catenaof coastal habitats

\subsection{Habitat parameters}

The elevation, climatic and soil parameters of the coastal locations of tiger beetles are given in Table 5. Locations of H. biramosa and L.(Lophyra) catena are significantly different in solar radiation and soil salinity (Table 5). The solar radiation of the locations of $H$. biramosa was significantly higher than that of $L$. (Lophyra) catena $(\mathrm{F}=10.19, \mathrm{P}<0.05)$ (Table 5, Figure A). Soil salinity of $H$. biramosa locations ranged from $0-0.1 \mathrm{ppt}$, while L. (Lophyra) catena was found on non-saline soils $(\mathrm{F}=9.00, \mathrm{P}<0.05)$ (Table 5, Figure B). Statistical differences were not found between the habitat parameters of the locations of tiger beetles and locations in which tiger beetles were not recorded (Table 6). 
Table 5: Habitat characteristics of the coastal locations of tiger beetle species

\begin{tabular}{|c|c|c|c|c|}
\hline Parameter & $\begin{array}{l}\text { All locations } \\
\qquad(\mathrm{N}=11)\end{array}$ & $\begin{array}{c}\text { Locations of } \\
\text { Hypaetha } \\
\text { biramosa } \\
(\mathrm{N}=6)\end{array}$ & $\begin{array}{c}\text { Locations of } \\
\text { Lophyra (Lophyra) } \\
\text { catena } \\
(\mathrm{N}=5)\end{array}$ & $\begin{array}{l}\text { Locations of } \\
\text { Myriochila } \\
\text { (Monelica) } \\
\text { fastidiosa } \\
(\mathrm{N}=1) \\
\end{array}$ \\
\hline Elevation (m) & $\begin{array}{r}3.97 \pm 1.41 \\
(0.00-9.75)\end{array}$ & $\begin{array}{r}2.06 \pm 1.51 \\
(0.00-8.00)\end{array}$ & $\begin{array}{r}7.10 \pm 2.37 \\
(0.00-9.75)\end{array}$ & 1.00 \\
\hline Air Temperature $\left({ }^{\circ} \mathrm{C}\right)$ & $\begin{array}{r}35.50 \pm 1.13 \\
(31.00-41.00)\end{array}$ & $\begin{array}{r}34.20 \pm 1.77 \\
(31.00-41.00)\end{array}$ & $\begin{array}{r}37.75 \pm 1.18 \\
(36.00-41.00)\end{array}$ & 33.00 \\
\hline $\begin{array}{l}\text { Solar Radiation } \\
\left(\mathrm{w} / \mathrm{m}^{2}\right)\end{array}$ & $\begin{array}{r}490.80 \pm 103.31 \\
(132.00-1023.00)\end{array}$ & $\begin{array}{c}734.20 \pm 127.61^{*} \\
(438.00-1023.00)\end{array}$ & $\begin{array}{c}244.25 \pm 57.46^{* *} \\
(132.00-402.00)\end{array}$ & 260.00 \\
\hline $\begin{array}{l}\text { Relative Humidity } \\
(\%)\end{array}$ & $\begin{array}{r}61.00 \pm 3.23 \\
(45.00-77.00)\end{array}$ & $\begin{array}{r}62.20 \pm 5.34 \\
(45.00-77.00)\end{array}$ & $\begin{array}{r}58.75 \pm 5.22 \\
(45.00-70.00)\end{array}$ & 64.00 \\
\hline Wind Speed (MPH) & $\begin{array}{r}6.70 \pm 2.52 \\
(0.00-22.00)\end{array}$ & $\begin{array}{r}4.00 \pm 1.92 \\
(0.00-9.00)\end{array}$ & $\begin{array}{r}7.00 \pm 5.07 \\
(0.00-22.00)\end{array}$ & 19.00 \\
\hline $\begin{array}{l}\text { Soil Temperature } \\
\left({ }^{\circ} \mathrm{C}\right)\end{array}$ & $\begin{array}{r}34.71 \pm 0.95 \\
(30.50-39.00)\end{array}$ & $34.00 \pm 0.00$ & $\begin{array}{r}36.13 \pm 0.97 \\
(35.00-39.00)\end{array}$ & 30.50 \\
\hline Soil Moisture (\%) & $\begin{array}{r}4.60 \pm 1.41 \\
(0.18-10.71)\end{array}$ & $\begin{array}{r}5.97 \pm 2.04 \\
(0.68-10.23)\end{array}$ & $\begin{array}{r}1.36 \pm 0.78 \\
(0.18-3.50)\end{array}$ & 10.71 \\
\hline Soil pH & $\begin{array}{r}7.62 \pm 0.15 \\
(7.00-8.20)\end{array}$ & $\begin{array}{r}7.82 \pm 0.16 \\
(7.40-8.20)\end{array}$ & $\begin{array}{r}7.50 \pm 0.29 \\
(7.00-8.00)\end{array}$ & 7.00 \\
\hline Soil Salinity (ppt) & $\begin{array}{r}0.06 \pm 0.02 \\
(0.00-0.20)\end{array}$ & $\begin{array}{l}0.08 \pm 0.03^{*} \\
(0.00-0.10)\end{array}$ & $0.00 \pm 0.00^{\text {** }}$ & 0.20 \\
\hline
\end{tabular}

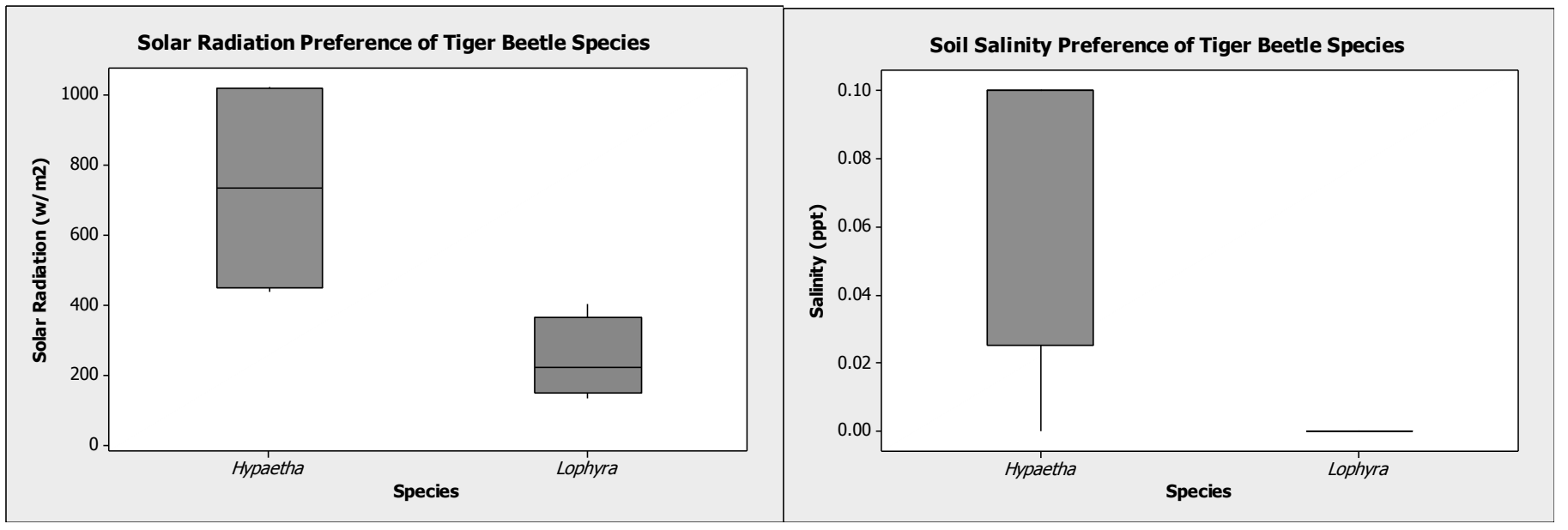

(A)

(B)

Figure 5: Variation of significant habitat parameters (A) Solar radiation (B) Soil salinity in coastal locations of Hypaetha biramosa and Lophyra (Lophyra) catena 
Table 6: Comparison of habitat characteristics of locations in which tiger beetles were recorded and not recorded

\begin{tabular}{lcr}
\hline \multicolumn{1}{c}{ Parameter } & \multicolumn{2}{c}{ Ocurrence of tiger beetles } \\
& Present $(\mathrm{n}=11)$ & Absent $(\mathrm{n}=11)$ \\
\hline Elevation $(\mathrm{m})$ & $3.97 \pm 1.41$ & $4.85 \pm 2.10$ \\
Air Temperature $\left({ }^{\circ} \mathrm{C}\right)$ & $35.50 \pm 1.13$ & $31.20 \pm 2.55$ \\
Solar Radiation $\left(\mathrm{w} / \mathrm{m}^{2}\right)$ & $490.80 \pm 103.31$ & $401.74 \pm 119.33$ \\
Relative Humidity $(\%)$ & $61.00 \pm 3.23$ & $66.82 \pm 2.38$ \\
Wind Speed $(\mathrm{MPH})$ & $6.70 \pm 2.52$ & $3.49 \pm 0.44$ \\
Soil Temperature $\left({ }^{\circ} \mathrm{C}\right)$ & $34.71 \pm 0.95$ & $32.89 \pm 0.24$ \\
Soil Moistuure $(\%)$ & $4.60 \pm 1.41$ & $3.98 \pm 0.95$ \\
Soil pH & $7.62 \pm 0.15$ & $7.78 \pm 0.65$ \\
Soil Salinity $(\mathrm{ppt})$ & $0.06 \pm 0.02$ & $0.05 \pm 0.01$ \\
\hline
\end{tabular}

\section{Discussion and Conclusions}

The present study revealed three species of tiger beetles, Hypaetha biramosa, Lophyra (Lophyra) catena, Myriochila (Monelica) fastidiosa, from coastal habitats of Sri Lanka. However, seven species have been reported from previous studies and collections that include H. biramosa and L. (Lophyra) catena whereas M. (Monelica) fastidiosa was recorded for the first time in the present study. According to previous literature, $H$. biramosa is the only tiger beetle species confined to the coastal habitats of the island. The other six species have been recorded on edges of rivers, lakes, grasslands, old fields and sunny forest clearings in addition to coastal habitats (Acciavatti and Pearson, 1989). L. (Lophyra) catena was encountered on banks of reservoirs and landscaped gardens by the first author during 2003 - 2004 (Dangalle et al., 2012a; Dangalle et al., 2012b). Therefore, the current absence of certain tiger beetle species from the coastal locations that they previously occupied maybe due to the extirpation of species from coastal habitats to other habitat types that they prefer. Cicindela hirticollis of North America which was abundant on wet beach sand, sandbars or moist pans within dune fields disappeared from many sites in the past 30-40 years because of increased beach usage and other human disturbance along the coast, and has been recovered from a few sites along rivers (Knisley and Fenster, 2005). Cicindela ohlone which occurred in coastal terrace grasslands of California, currently occupies densely vegetated grasslands with dirt trails and trails used by mountain bikers and walkers (Knisley, 2011).

Hypaetha quadrilineata showed a rapid dispersal to inland habitats when local conditions became unfavourable along the coastal beaches of Iran (Acciavatti and Pearson, 1989). Further, the endemic tiger beetle species, Cicindela (Ifasina) willeyi of Sri Lanka is known to have extirpated from it's historical locations to new locations due to the unsuitability and loss of its former habitats (Dangalle et al., 2011a). The endemic species, Cicindela (Ifasina) waterhousei has also become locally displaced from its previous locations to a single riverine location of the island (Dangalle et al., 2011b). Therefore, the tiger beetle species that once occupied the coastal locations of Sri Lanka may currently exist in other locations with suitable habitat conditions which they prefer. However, investigations in some previous coastal locations of tiger beetles from which species are not currently recorded revealed similar habitat conditions to that of the locations in which tiger beetles were recorded (Table 6). Therefore, further investigations focusing on prey availability and abundance, and predators of tiger beetles are required to explain the non-availability of 
certain tiger beetle species along the coastal belt. Investigations of the historical locations of tiger beetles including locations of the Northern province (Kilinochchi, Pesalai, Mannar) and Eastern province (Nilaveli, Trincomalee, Kalkudah, Pottuvil) which could not be investigated due to security conditions that prevailed in the country at that time are also required.

Our results revealed the presence of tiger beetles in the same locations even after the tsunami of 2004. However, the immediate impacts of the tsunami were not assessed in the present study and the coastal habitats can be expected to have recovered over several months providing bare ground for tiger beetles to encounter mates, oviposit and find prey.

M. (Monelica) fastidiosa has been reported from old fields, grasslands and forest paths (Acciavatti and Pearson, 1989). Further, the species was encountered by the first author from four reservoir ecosystems of the island during 2004 - 2005 (Dangalle et al., 2012a). Currently, the reservoir ecosystems of Sri Lanka are dominated by the tiger beetle Calomera angulata which occurs as large single species populations or cooccurs with other tiger beetle species (Dangalle et al., 2012a). M. (Monelica) fastidiosa co-occurred with Calomera angulata in three of the reservoir ecosystems that it occupied and was only found as a single species population in the Nuwarawewa reservoir (Dangalle et al., 2012a). Co-occurring tiger beetle species are known to compete for food resources, ovipositional sites and mating (Tigreros and Kattan, 2008; Brosius, 2010). Cicindela nevadica lincolniana of the saline habitats of Nebraska that co-occurs with three other species of tiger beetles has suffered a drastic decline in population due to competition for food resources and oviposition sites (Brosius, 2010). Further, Cicindela hirticollis abrupta of Sacramento Valley, California has disappeared from most of it's historic range while another tiger beetle Cicindela oregona was found at these sites (Knisley and Fenster, 2005). C. (Ifasina) waterhousei of Sri Lanka is also known to have become locally displaced from its previous locations due to competition for food, thermal resources, oviposition sites and larval resources by other tiger beetle species (Dangalle et al., 2011b). Therefore, the incidence of $M$. (Monelica) fastidiosa in a coastal habitat maybe an indication of the species exploiting a new habitat due to competition exerted by co-occurring tiger beetle species.

When considering the coastal habitats of species, $H$. biramosa was found on sandy beaches near the swash while L. (Lophyra) catena occurred in habitats away from the beach amongst coastal vegetation. These two microhabitats were similar in most of the climatic and soil characteristics but differed significantly in solar radiation and soil salinity. Microhabitat characteristics are important in tiger beetle oviposition site choice and females have been shown to choose sites based on shade, soil type, salinity, moisture and vegetation cover (Cornelisse et al., 2013). Certain species prefer hot, dry conditions and find suitable moist soils for oviposition and larval development. For example Cicindela limbata albissima which has evolved as a sand dune specialist tolerates hot, dry, sunny conditions whereas generalist species are less tolerant of these conditions (Romey and Knisley, 2002). Likewise, H. biramosa which has been confined to the coastal habitats of the island since historical times may have evolved to tolerate high solar radiation conditions in contrast to the more generalist species L. (Lophyra) catena.

Oviposition site selection of tiger beetles is also based on soil salinity and certain species prefer saline soils while others prefer non-saline soils. Salinity of soils have a negative impact on vegetation and produces dry sunny habitats lacking shade (Brosius, 2010). According to Dangalle et al. (2012b) soil salinity is an important factor determining habitat specificity of $H$. biramosa of Sri Lanka.

$H$. biramosa and L. (Lophyra) catena are medium-sized beetles with similar color pattern. $L$. (Lophyra) catena is slightly smaller than $H$. biramosa and this difference tends to be significant $(\mathrm{p}<0.05)$. However, the two species have similar mandible lengths that indicate preference for prey of similar size. Therefore, it is highly possible that habitat segregation of H. biramosa and L. (Lophyra) catena is not influenced by the size of prey in microhabitats. The present study strongly indicates that physiological preferences that are conservative and characteristic for the two species determine their utilization of different microhabitats. 
Acknowledgements: We wish to thank the National Science Foundation of Sri Lanka (Research Grant No. $\mathrm{RG} / 2003 / \mathrm{ZOO} / 01$ ) for funding the present study. We are also greatly indebted to the Department of Zoology, University of Colombo; the Natural History Museum of London, United Kingdom and the Department of Wildlife Conservation of Sri Lanka. We are grateful to Prof. Nimal Dangalle and Ms. Dinesha Senarathna, Department of Geography, University of Kelaniya, Sri Lanka for their assistance in the preparation of maps and locational lists.

\section{References}

Acciavatti, R.E., Pearson D.L., 1989. The tiger beetle genus Cicindela (Coleoptera, Insecta) from the Indian subcontinent. Annals of Carnegie Museum. 58(4), 77-355.

Brosius, T.R., 2010. Niche specialization and conservation biology of Cicindela nevadica lincolniana. Dissertations and Student Research in Entomology, University of Nebraska, Lincoln, pp. 130.

Cornelisse, T.M., Vasey, M.C., Holl, K.D., Letourneau, D.K., 2013. Artificial bare patches increase habitat for the endangered Ohlone tiger beetle (Cicindela ohlone). Journal of Insect Conservation. 17(1), 17-22.

Dangalle, C., Pallewatta, N., Vogler, A., 2011a. The current occurrence, habitat and historical change in the distributional range of an endemic tiger beetle species Cicindela (Ifasina) willeyi Horn (Coleoptera: Cicindelidae) of Sri Lanka. Journal of Threatened Taxa. 3(2), 1493-1505.

Dangalle, C., Pallewatta, N., Vogler, A.,2011b. The occurrence of the endemic tiger beetle Cicindela (Ifasina) waterhouseiin Bopath Ella, Ratnapura, Sri Lanka. Journal of the National Science Foundation of Sri Lanka. 39(2), 163-168.

Dangalle, C., Pallewatta, N., Vogler, A., 2012a. Tiger beetles (Coleoptera: Cicindelidae) of ancient reservoir ecosystems of Sri Lanka. Journal of Threatened Taxa. 4(4), 2490-2498.

Dangalle,C.D., Pallewatta, N., Vogler, A.P. 2012b. Habitat specificity of tiger beetle species (Coleoptera, Cicindelidae) of Sri Lanka. Cicindela.44(1), 1-32.

Fowler, W.W.,1912. Fauna of British India including Ceylon and Burma \{Coleoptera general introduction and Cicindelidae and Paussidae\}, Today and Tomorrow's Printers and Publishers, New Delhi.

Horn, W., 1904. The Cicindelidae of Ceylon. Spolia Zeylanica. 2(5), 30-45.

IUCN, 2002. Regional technical assistance for coastal and marine resource management and poverty reduction in South Asia (ADB RETA 5974) - Situation Analysis Report: Sri Lanka Component.

Knisley, C.B., Fenster, M.S., 2005. Apparent extinction of the tiger beetle, Cicindela hirticollis abrupt (Coleoptera: Carabidae: Cicindelinae). The Coleopterists Bulletin. 59(4), 451-458.

Knisley, C.B., 2011. Anthropogenic disturbances and rare tiger beetle habitats: benefits, risks, and implications for conservation. Terrestrial Arthropod Reviews. 4, 41-61.

Lowry, K., Wickremeratne, H.J.M., 1988. Coastal area management in Sri Lanka. Coastal Management. 263-293.

Mawdsley, J.R., 2009. Taxonomy, ecology, and phylogeny of species of Lophyra Motschulsky 1859, subgenus Eriolophyra Rivalier 1948 (Coleoptera Cicindelidae). Tropical Zoology. 22, 57-70.

McCairns, R.F., Freitag, R., Rose, H.A., McDonald, F.J.D.,1997. Taxonomic revision of the Australian Cicindelidae (Coleoptera), excluding species of Cicindela. Invertebrate Taxonomy.11, 599-687.

Morgan, M.M., Knisley, C.B., Vogler, A.P., 2000. New taxonomic status of the endangered tiger beetle Cicindela limbata albissima (Coleoptera: Cicindelidae): Evidence from mtDNA. Annals of the Entomological Society of America. 93(5), 1108-1115.

Naviaux, R.,1984.Coleoptera, Cicindelidae. Les Cicindelés de Sri Lanka. Revue Scientifique Du Bourbonnais. 57-80. 
Pearson, D.L., Juliano, S.A.,1993. Evidence for the influence of historical processes in co-occurrence and diversity of tiger beetle species, in: Ricklefs, R.E., Schulter, D. (Eds.),Species diversity in Ecological Communities. Chicago University Press, Chicago, pp. 194-202.

Pearson, D.L., 1988. Biology of tiger beetles. Annual Review of Entomology. 33, 123-147.

Pearson, D.L., 2011. Six-legged tigers. Spring. 19-23.

Rafi, M.A., Jurgen, W., Matin, M.A., Zia, A., Sultan, A., Naz, F., 2010. Faunistics of tiger beetles (Coleoptera: Cicindelidae) from Pakistan. Journal of Insect Science. 10, 1-23.

Romey, W.L., Knisley, C.B., 2002. Microhabitat segregation of two Utah sand dune tiger beetles (Coleoptera: Cicindelidae). The Southwestern Naturalist. 47(2), 169-174.

Satoh, A., Hori, M., 2004.Interpopulation differences in the mandible size of the coastal tiger beetle Lophyridia angulata associated with different sympatric species. Entomological Science. 7, 211-217.

Satoh, A., Ueda, T., Enokido, Y., Hori, M., 2003. Patterns of species assemblages and geographical distributions associated with mandible size differences in coastal tiger beetles in Japan. Population Ecology. 45, 67-74.

Tigreros, N., Kattan, G.H., 2008. Mating behavior in two sympatric species of Andean tiger beetles (Cicindelidae). Boletin del Museo de Entomologia de la Universidad del Valle. 9(1), 22- 28.

Wiesner, J., 1975. Notes on Cicindelidae of India and Sri Lanka. Cicindela. 7(4), 61-70.

Wiesner, J.,1992. Checklist of the tiger beetles of the world (Coleoptera: Cicindelidae), Verlag Erna Bauer, Keltern, Germany.

Zerm,M., Adis, J.,2001. Spatio-temporal distribution of larval and adult tiger beetles (Coleoptera: Cicindelidae) from open habitats in Central Amazonian floodplains (Brazil). Studies on Neotropical Fauna and Environment.36(3), 185-198. 